\title{
Karolina Markowska
}

\section{Struktura i organizacja prowincji rzymskich - wprowadzenie do zagadnień prawno-ustrojowych}

\section{STRESZCZENIE}

Niniejszy artykuł stanowi wprowadzenie do zagadnień prawno-ustrojowych organizacji prowincji rzymskich na terenach podbitych w okresie największego rozkwitu Cesarstwa Rzymskiego (I-III w n.e.). Nakreśla on podział administracyjny imperium, relacje między nimi a Rzymem.

Sprawne i zorganizowane zarządzanie ogromnym terenem przy pomocy ustrukturyzowanego aparatu urzędniczego, pozwoliło Rzymianom przez kilka stuleci zapanować nad powierzchnią tysięcy kilometrów kwadratowych i stworzyć imperium światowe. Do najważniejszych zadań princepsa należało zapewnienie zewnętrznego i wewnętrznego bezpieczeństwa cesarstwa, ustrukturyzowanie i rozwój sprawnej administracji zarządczej państwa, jak również gwarancja funkcjonowania właściwego/poprawnego sądownictwa. Nie bez znaczenia pozostawał mechanizm pobierania podatków, które wzbogacały cesarski skarbiec i świadczyły o potędze władcy.

Imperium funkcjonowało w oparciu o strukturę prowincji, kolonii i municypiów, gdzie te ostatnie stanowiły podstawową formę lokalnej autonomii. Organizacja aparatu urzędniczego była w dużej mierze wzorowana na ustroju republikańskiego Rzymu, z poszanowaniem tradycji miejscowych. Mimo swego uzależnienia, ludność miejscowa nadal posiadała pełną decyzyjność we własnych sprawach.

Słowa kluczowe: prowincje rzymskie, kolonia rzymska, municypium 


\title{
Karolina Markowska
}

\section{The structure and the organization of the Roman province - an introduction to the legal and political issues}

\begin{abstract}
The following article provides an introduction to the issues of legal and political organization of the Roman provinces in the area of conquered territory in the time of the Roman Empire (I-III A.D). It outlines the administrative division of the empire, the relationship between them and Rome.

An efficiency and well-organized management of the huge land using structured magistrate, allowed the Romans to create a world Empire which prevailed over a thousand square kilometers. The most important tasks of princeps was to ensure external and internal security of the Empire by structured and efficiency administration, as well as a guarantee of the proper/ correct jurisdiction. Not without significance was the tax collection which enriched the imperial treasury and testified to the power of the ruler.

The Roman state was based on provinces, colonies and municipalities, where the last one were the primary form of local autonomy. The organization of official structure was largely modeled on the system of the Republican Rome, while respecting local traditions at the same time. Although their dependence, the residents still had full decision-making in their own affairs.
\end{abstract}

Keywords: Roman provinces, Roman colony, municipium 
Provinciae sunt praedia populi Romani ${ }^{1}$

\section{STRUKTURAUSTROJOWA-PODZIAŁADMINISTRACYJNY IMPERIUM ROMANUM}

Imperium Rzymskie nigdy nie stanowiło jednolitej organizacji państwowej, mimo tak rozległego terytorium. Była to de facto luźna federacja silnie uzależnionych od Rzymu państewek o różnym statusie. Celem artykułu jest przybliżenie podstawowych form, które wyznaczały rodzaj więzi z Wiecznym Miastem, a w konsekwencji umożliwiły stworzenie formacji, która na wieki zdominowała europejską kulturę, w szczególności system prawny.

Podboje i aneksja nowych ziem stanowiły o potędze i sile Rzymu. Systematycznie powiększany obszar państwa wymagał nie tylko sprawnego zarządzania nowymi terenami, ale również koordynacji podbitych ludów - odmiennych od Rzymian pod względem kulturowym, religijnym i mentalnym. Z pełną świadomością odrębności ludów, będących w zasięgu planów ekspansji, Rzymianie stosowali praktyczną zasadę divide et impera ${ }^{2}$. Efektywnie zdołali tym sposobem opanować Półwysep Apeniński, Galię, Hiszpanię, a docelowo dalsze tereny. Finalnie w sprawny sposób stworzyli imperium światowe, bo w powszechnym rozumowaniu tamtejszych czasów, to właśnie Rzym stanowił mirabilia mundi.

Wraz ze zwycięstwem wojen latyńskich i rozwiązaniem Związku Latyńskiego około 338 roku p.n.e. Rzymianie rozpoczęli podbój Półwyspu Apenińskiego ${ }^{3}$. Część miast wcielono do państwa rzymskiego, niektóre utrzymały charakter sprzymierzeńców Rzymu (socii). Znaczenia nabrał problem wyżywienia rozrastającego się państwa-miasta i przybywającej liczby ludności. Podbój nowych ziem miał służyć w pierwszej kolejności właśnie zaopatrzeniu obywateli rzymskich pod względem materialnym - zdobyciu nowych źródeł płodów rolnych, jak i finansowym - zdobyciu nowych źródeł

1 M.T. Cicero, Orationes, In Verrem li 2-7; przez wieki prowincje rzymskie były źródłem bogactw zarówno państwa rzymskiego, jak i przedstawicieli klasy panującej, w świadomości mieszkańców Rzymu były uważane za zdobycz ludu rzymskiego.

2 M. Kaser, Römische Rechtsgeschichte, Göttingen 1967, s. 55.

3 M. Jaczynowska, Historia starożytnego Rzymu, Warszawa 1979, s. 62. 
podatków ${ }^{4}$. Proces dalszych podbojów, rozpoczęty aktywnie przed I wojną punicką w 238 roku p.n.e., z najbardziej spektakularnym okresem podbojów Augusta (27 r. p.n.e.-14 r. n.e.) i Trajana (98-117 r. n.e.), zakończył w pełni świadomie Hadrian (117-138 r. n.e.). W połowie II wieku n.e. Cesarstwo Rzymskie liczyło 40 prowincji, niektóre źródła mówią o $44^{5}$.

Sprawnemu zarządzaniu tak dużym obszarem służył aparat urzędniczy, który wzorowany był na rzymskim ustroju republikańskim, ale dopasowanym do realiów lokalnych społeczności. Rzymianie mieli duże poszanowanie dla miejscowych struktur, obyczajów i religii. Widzieli się raczej w roli koordynatorów zdobytych terenów i na tym opierali tworzony przez siebie system administracyjny.

Rozróżnić należy dwie główne strefy wpływów rzymskich: Italię i prowincje. Na terenie Italii i Hiszpanii system organizacji miast wzorowany był na ustroju republikańskiego Rzymu, opartym na formie kolonii i municypium. Natomiast w Afryce Północnej i w Azji zachowano jeszcze przedrzymski system organizacji miast ${ }^{6}$. Różnice te uległy stopniowemu zatarciu w wyniku podbojów epoki pryncypatu.

W zależności od położenia i funkcji podległego obszaru można wyróżnić mniej lub bardziej spajające formy powiązania z Rzymem. Struktury te ewaluowały w czasie rozwoju Imperium, tj. na przestrzeni lat jedne $z$ nich dominowały, niektóre zupełnie zanikały, a pomiędzy innymi zacierała się różnica znaczeniowa. Można wyróżnić dwa systemy romanizacji terenów podbitych: na zachodzie Imperium, czyli tereny Italii, Galii, Hiszpanii, ale też Afryki Północnej, były zorganizowane na wzór rzymskiego ustroju republikańskiego; organizacja prowincji na ziemiach zdobywanych na wschodzie opierała się na systemie greckiego poleis ${ }^{7}$. Był to $\mathrm{w}$ dużej mierze obszar

4 W. Eck, Die Struktur der Städte in den nordwestlichen Provinzen und ihr Beitrag zur Administration des Reiches, [w:] W. Eck-H.Gailsterer (red.), Die Stadt in Oberitalien und den nordwestlichen Provinzen des römischen Reiches, Kölner Forschungen 4, Mainz 1991, s. 73.

5 T. Bechert, Die Provinzen des Römischen Reiches. Einführung und Überblick, Mainz 1999, s. 74; W. Bojarski, Stosunki cesarskiego Rzymu z lokalnymi autonomiami w zakresie sadownictwa, [w:] Dzieje wymiaru sprawiedliwości, Koszalin 1999, s. 11; W. Eck, Die Verwaltung des Römischen Reiches in der Hohen Kaiserzeit: ausgewählte und erweiterte Beiträge, t. 2, Basel-Berlin 1997, s. 109.

6 B. Sitek, Lex coloniae Genetivae Iuliae seu Ursonensis i Lex Irnitiana. Ustawy municypalne antycznego Rzymu. Tekst, tłumaczenie i komentarz, Poznań 2008, s. 14.

7 Po raz pierwszy pojęcia, ,romanizacja” użył Tertulian, teolog łaciński z Afryki Północnej, jako romanista zamieszkały w Afryce opanowanej przez rzymską kulturę. Określił tym pojęciem wszystko, co odnosiło się do rzymskiego sposobu myślenia, proces asymilacji, a więc również dopasowania rzymskich struktur administracyjnych do lokalnych tak, aby jak najefektywniej podporządkować zdobyte tereny władzy Rzymu. 
podbity przez Aleksandra Wielkiego. Struktura systemu wschodniego nie jest przedmiotem tego opracowania.

Wyrazem ujednolicenia struktur, o czym traktuje ten artykuł, było nadawanie statusu zdobytym terenom: miastom italskim, miastom prowincjonalnym, koloniom - w formie lex municipalis lub lex coloniae. Ustawa nadana przez Rzym była podstawową regulacją funkcjonowania lokalnej organizacji, jej zarządzania, finansowania, stosunków zewnętrznych. Do czasów współczesnych zachowało się kilkanaście takich ustaw, które są nieocenionym źródłem wiedzy na temat starożytnego samorządu miejskiego ${ }^{8}$.

\subsection{Kolonia}

Kolonie były zakładane przez Rzymian stosunkowo wcześnie na terenach podbitych Italii, a później także w dalszych odległościach. Lokowane najczęściej w punktach strategicznych, np. w portach czy na szlakach handlowych, były formą militarnego podporządkowania terenu podbitego władzy Rzymu. Zakładano je w dużej mierze z myślą o zaopatrzeniu weteranów wojennych, wraz z ich licznymi rodzinami, i umocnieniu władzy rzymskiej na podbitym terenie ${ }^{9}$. Jednocześnie kolonie rozwiązywały problem głodu ziem, ponieważ przesiedlano tu biedotę miejską z Rzymu i zasiedlano tereny publiczne (ager publicus) ${ }^{10}$. Zachętą do przesiedlenia były stosunkowo duże nadziały gruntów.

Ustrój kolonii był wzorowany na rzymskiej civitas. Z czasem wyróżnić można było kolonie rzymskie (coloniae civium Romanorum) oraz kolonie na prawie latyńskim (colonie Latinae). Wysłani z Rzymu mieszkańcy kolonii rzymskich posiadali pełnię praw obywateli Rzymu w zakresie prawa pry-

8 Ustawy były najczęściej wyryte na kamiennych stelach i ustawione w centralnym punkcie miasta. Ze względu na materiał nośny możliwe było zachowanie materiałów źródłowych do czasów obecnych. Najbardziej znane to m.in. lex Osca tabulae Bantinae, lex pompeia, lex municipii Tarentini, lex de Galia cisalpina, Fragmentum atestinum, lex Coloniae Genetivae Juliae seu Ursonensis, lex civitatis narbonensis de flamonio provinciae, lex municipii salpensani, lex municipii malacitani - ustawy zebrane w: Fontes luris Romani Anteiustiniani (iterum edidit S. Riccobono), I. Pars prima - leges, Caput IV - leges datae, Florentiae 1941 (dalej: FIRA).

9 Więcej o wojskowym charakterze kolonii: H. Hurst, The fortress coloniae of Roman Britain: Colchester, Lincoln and Gloucester, [w:] J.H. Humphrey, S.B. Holman (red.), „Journal of Roman Archaeology”, nr 38; tak samo tłumaczy A. Berger, Encyclopedic Dictionary of Roman Law, Philadelphia 1953 (reprint z 1980) s. 397, jako rozpowszechnienie kolonizacji dla celów wojskowych, wojennych, politycznych i komercyjnych. ${ }^{10}$ R. Sajkowski, Kwestie ustrojowe - rys historyczny, [w:] A. Jurewicz i in., Rzymskie Prawo publiczne. Wybrane zagadnienia, Olsztyn 2011, s. 46; M. Jaczynowska, op. cit., s. 69. 
watnego, jak i publicznego, tzn. mogli ubiegać się o wszystkie urzędy publiczne w Rzymie ${ }^{11}$. Kolonie rzymskie były położone stosunkowo blisko Rzymu i miały stanowić swoiste przedłużenie ojczyzny na obcej ziemi, dlatego nie miały autonomii ${ }^{12}$. Kolonie latyńskie miały autonomię bardzo szeroką - posiadały m.in. własne organy administracyjne. Były liczne, a cel ich powołania był zbieżny z koloniami rzymskimi. Mieszkańcy tych kolonii cechowali się niższym statusem społecznym, musieli zrzec się obywatelstwa rzymskiego, a ich sytuacja prawna była podobna do dawnych Latynów, tj. nie mieli prawa głosowania i sprawowania urzędów publicznych ${ }^{13}$. W wyjątkowych sytuacjach mieli prawo do zawierania aktów prawa cywilnego w zakresie obrotu gospodarczego (ius comercii) oraz do zawierania małżeństw, wywierających skutki według ius civile ${ }^{14}$. Poprzez ponowne osiedlenie się w Rzymie nabywali obywatelstwo rzymskie (ius migrandi). Spotyka się przykłady nadania obywatelstwa rzymskiego lokalnym urzędnikom ${ }^{15}$.

$Z$ końcem republiki kolonie zakładano na podstawie uprawnień władczych dowódcy wojskowego, jego imperium ${ }^{16}$, a w okresie pryncypatu także na mocy konstytucji cesarza ${ }^{17}$. Spotykane są również przypadki zakładania kolonii przez kobiety. Najbardziej znanym jest założenie Colonia Claudia Ara Agrippinensium, czyli dzisiejszej Kolonii ${ }^{18}$.

\subsection{Municypium}

Mianem municypium określano niezależne miasto prowincjonalne, którego przeciwieństwem było urbs, pojęcie zarezerwowane tylko i wyłącznie dla Rzymu $^{19}$. Ustrój poszczególnych municypiów był wzorowany w znacznym

11 J. Zabłocki, A. Tarwacka, Publiczne prawo rzymskie, Warszawa 2011, s. 111; B. Sitek, Lex coloniae..., op. cit., s. 15.

12 M. Kaser, op. cit., s. 57; W. Bojarski, op. cit., s. 13.

13 B. Sitek, Autonomie lokalne - municypia, [w:] A. Jurewicz i in., op. cit., s. 263; J. Zabłocki, A. Tarwacka, op. cit., s. 111.

14 M. Kaser, op. cit., s. 58.

15 Decretum cn. Pompei Strabonis (Lex Pompeia) de civitatie equitibus hispanis danda, FIRA I, 17, op. cit., s. 165.

16 Przykładem są chociażby kolonie: Urso w Hiszpanii oraz Curubis, Clupea w Afryce założone przez Juliusza Cezara.

17 B. Sitek, Autonomie..., op. cit., s. 265.

18 Zob. W. Eck, Agrippina - die Stadtgründerin Kölns. Eine Frau in der frühkaiserzeitlichen Politik, Köln 1993.

${ }_{19}$ Mūnı̌cĭp̌ŭm, -i-miasto prowincjonalne, za K. Kumaniecki, Słownik łacińsko-polski, Warszawa 1975, s. 318; tak samo A. Berger, op. cit., s. 590. Sondel podkreśla natomiast utratę niezawisłości mieszkańców 
stopniu na ustroju republikańskim ${ }^{20}$. Jednostki posiadały własne organy władzy, których autonomia była określona w ustawie municypalnej-lex municipalis, uchwalanej przez zgromadzenie ludowe w Rzymie. Miała ona charakter lex rogata. $Z$ czasem uprawnienia municypalne nadawali dowódcy wojskowi i cesarz, wtedy były to już leges datae. Mieszkańcy municypium mieli ograniczone prawa obywatelskie - civitatessine suffragio, tzn. byli obywatelami rzymskimi bez prawa do głosowania i kandydowania na urzędy ${ }^{21}$.

Z czasem różnice prawno-ustrojowe pomiędzy kolonią a municypium zacierały się, a kolonia stanowiła jednostkę bardziej prestiżową: meliore condicione esse colonias quam municipia ${ }^{22}$. Kolonia jawiła się raczej jako cel ambicjonalny miast romanizujących się ${ }^{23}$. Lepsze położenie mieszkańców kolonii polegało również na tym, że ich terytorium było objęte ius Italicum, a więc zwolnione z ciężaru podatkowego ${ }^{24}$, natomiast mieszkańcy municypium ponosili pewne ciężary na rzecz Rzymu (munera), np. obowiązek płacenia podatków czy odbycia służby wojskowej.

W dalszej części artykułu pojęcie municypium i jego organizacji odnosi się również do organizacji kolonii. Jeżeli w danej sytuacji nie można ujednolicić pojęć, jest to wyraźnie zaznaczone.

\subsection{Prowincja}

Jako prowincje określano pozaitalskie tereny podbite przez Rzym w okresie wielkich podbojów. Pierwotnie pod pojęciem prowincji rozumiano zakres pełnomocnictwa, które powierzono urzędnikowi w sprawowaniu urzędu ${ }^{25}$. Mogło to być np. uprawnienie do prowadzenia wojny, zarządzanie kasą państwową przez kwestora czy wydawanie wyroków w Rzymie. Od czasów podbojów rzymskich poza Italią określenie „prowincja” nabrało

municypium w wyniku podbojów - J. Sondel, Słownik łacińsko-polski dla prawników i historyków, Kraków 1997 , s. 644.

20 B. Sitek, Lex coloniae..., op. cit., s. 16.

21 R. Sajkowski, op. cit., s. 46; więcej: M. Humbert, Municipium et civitas sine suffragio. L'organisation de la conquétejusqu'a la guerre sociale, Rzym 1978.

22 Aulus Gell. XVI 13,3.

23 T. Bechert, Germania inferior. Eine Provinz an der Nordgrenze des Römischen Reiches, Mainz 2007, s. 38; T. Kotula, Z badań nad ustrojem municypalnym epoki późnego Cesarstwa. Afrykańskie municypia i kolonie, „Przegląd Historyczny" 1973, z. 3, s. 446.

24 M. Kaser, op. cit., s. 95.

25 R. Sajkowski, op. cit., s. 47. 
nowego znaczenia. Było wtedy rozumiane jako określony teren podległy władzy rzymskiego urzędnika - przedstawiciela imperium ${ }^{26}$. Jeżeli chodzi o zakres terytorialny, to prowincja jest najszerszym z omawianych pojęć.

Status prawny prowincji regulowała lex provinciae, uchwalana przez senat $\mathrm{w}$ momencie wcielenia prowincji do obszaru Imperium. Obejmowała ona swoją mocą cały teren, łącznie z poszczególnymi miastami, wchodzącymi w skład prowincji. Należy rozumieć, że w skład pojedynczej prowincji mogły wchodzić municypia i kolonie, które miały swoje oddzielne statusy organizacji wewnętrznych. Prowincja rzymska nie może być rozumiana jako obszar jednolity administracyjnie. Były to raczej tereny pozaitalskie, przy stałej obecności wojsk rzymskich, bez własnej państwowości ${ }^{27}$.

Ogół wolnych mieszkańców prowincji stanowił najbardziej liczną grupę w społeczeństwie rzymskim. Jednocześnie ludność nierzymska była bardzo zróżnicowana ${ }^{28}$. Nie można bowiem zestawić mieszkańca greckiego polis z mieszkańcem północnoafrykańskich prowincji. Dzieliło ich wiele, przede wszystkim styl życia, kultura, mentalność. Tym samym obowiązek namiestnika prowincji, jakim było zapewnienie porządku w prowincji, miał kolosalne znaczenie.

Od czasów Augusta system prowincji ulegał stopniowemu zróżnicowaniu pod względem administracyjnym, co spowodowało wyróżnienie prowincji cesarskich - provinciae Caesaris oraz prowincji ludu rzymskiego provinciae populi Romani. Nie do końca właściwe jest powszechne nazywanie tych drugich prowincjami senatorskimi. Na mylne określenie mogło wpłynąć to, że namiestnicy tych prowincji w randze konsula wywodzili się bezpośrednio ze stanu senatorskiego i byli powoływani na swoją funkcję przez senat. Od czasów Augusta istniały także prowincje zarządzane przez namiestnika będącego prokuratorem, np. Judea ${ }^{29}$.

Początkowo na czele prowincji stali pretorzy, a ich liczba zależała od liczby prowincji ${ }^{30}$. W przypadkach szczególnych, np. na wypadek wojny,

\footnotetext{
26 Prōvincĭă, ae - K. Kumaniecki, op. cit., s. 405, jako pierwsze znaczenie wymienia urząd, zakres działania, dowództwo, komendę, a dopiero następne znaczenie rozumianej dziś prowincji; tak samo A. Berger, op. cit., s. 559 i J. Sondel, op. cit., s. 802.

27 M. Kaser, op. cit., s. 93.

28 K. Christ, Die Römische Kaiserzeit, München 2001, s. 56.

29 Więcej o prowincjach zarządzanych przez prokuratorów: W. Eck, Die Leitung und Verwaltung einer prokuratorischen Provinz, [w:] Die Verwaltung des Römischen Reiches in der hohen Kaiserzeit. Ausgewählte und erweiterte Beiträge, t. 1, Basel-Berlin 1995, s. 327 i nast.
}

30 J. Zabłocki, A. Tarwacka, op. cit., s. 112. 
sprawy dotyczące prowincji powierzano konsulowi. Po przyłączeniu do Rzymu Macedonii i Afryki w 146 roku p.n.e. istniało więcej prowincji niż urzędników uprawnionych do kierowania nimi. Nieudolność takiego systemu zarządzania doprowadziła do tego, że coraz częściej senat przedłużał okres sprawowania namiestnictwa nad prowincją na więcej niż rok, tzw. prorogatio imperii. W ten sposób pojawili się prokonsulowie i propretorzy, którzy po zakończeniu swojej kadencji otrzymywali w zarząd prowincje ${ }^{31}$. Mieli oni uprawnienia administracyjne, wojskowe i jurysdykcyjne.

Podział kompetencji w zarządzaniu prowincjami cesarskimi i prowincjami ludu rzymskiego ilustruje poniższa tabela:

\begin{tabular}{|c|c|c|}
\hline & $\begin{array}{l}\text { Prowincje ludu rzymskiego } \\
\text { provinciae populi Romani }\end{array}$ & $\begin{array}{l}\text { Prowincje cesarskie } \\
\text { provinciae Caesaris }\end{array}$ \\
\hline Położenie & $\begin{array}{l}\text { w zasadzie usytuowane } \\
\text { wewnątrz Imperium }\end{array}$ & $\begin{array}{l}\text { ulokowane w obszarach } \\
\text { nadgranicznych Imperium }\end{array}$ \\
\hline Terytorium* & $\begin{array}{l}\text { ok. 10: Sardynia, Betyka, } \\
\text { Afryka, Numidia, Azja, Achaja, } \\
\text { Dalmacja, Egipt, Macedonia, } \\
\text { Sycylia, Kreta, Bitynia }\end{array}$ & $\begin{array}{l}\text { ok. } 40 \text {, m.in. Brytania, } \\
\text { Germania superior, Germania } \\
\text { inferior, Moesia, Syria, Belgica, } \\
\text { Lusitania }\end{array}$ \\
\hline Zarządzanie & $\begin{array}{l}\text { namiestnik powołany przez } \\
\text { senat na rok, wywodzący się } \\
\text { ze stanu senatorskiego - praeses } \\
\text { provinciae, w randze zarówno } \\
\text { prokonsula, jak i propretora }\end{array}$ & $\begin{array}{l}\text { namiestnik powoływany } \\
\text { bezpośrednio przez cesarza } \\
\text { - praesides provinciae; okres } \\
\text { urzędowania był różny: } \\
6-7 \text { lat, } 3 \text { lata, ponad } 10 \text { lat }\end{array}$ \\
\hline $\begin{array}{l}\text { Urzędnicy } \\
\text { towarzyszący }\end{array}$ & $\begin{array}{l}\text { namiestnicy prowincji } \\
\text { senackich mieli do pomocy } \\
\text { legatów (legati proconsulis } \\
\text { pro praetore), kwestorów, } \\
\text { odpowiedzialnych za sprawy } \\
\text { skarbowe; dodatkowo } \\
\text { urzędnicy pomocniczy: } \\
\text { liktorzy, skrybowie }\end{array}$ & $\begin{array}{l}\text { namiestnicy prowincji } \\
\text { cesarskich mieli do pomocy } \\
\text { legatów (legati Augusti } \\
\text { pro praetore); za sprawy } \\
\text { skarbowe odpowiedzialni byli } \\
\text { prokuratorzy (procuratores) } \\
\text { - wywodzący się ze stanu } \\
\text { ekwitów, odpowiedzialni } \\
\text { bezpośrednio przed } \\
\text { cesarzem; podlegali kontroli } \\
\text { przeprowadzanej przez } \\
\text { correctores civitatum } \\
\text { liberarium }\end{array}$ \\
\hline
\end{tabular}

31 R. Sajkowski, op. cit., s. 47. 
cd. tabeli

\begin{tabular}{|c|c|}
\hline $\begin{array}{l}\text { Sprawy } \\
\text { wojskowe } \\
\text { w przypadku } \\
\text { obecności } \\
\text { garnizonu }\end{array}$ & $\begin{array}{l}\text { legati legionis - powoływany } \\
\text { przez cesarza, ale podległy } \\
\text { namiestnikowi }\end{array}$ \\
\hline Nadzór & $\begin{array}{l}\text { faktyczny nadzór nad } \\
\text { prowincjami senackimi miał de } \\
\text { facto cesarz z tytułu imperium } \\
\text { maius }\end{array}$ \\
\hline \multicolumn{2}{|c|}{$\begin{array}{l}\text { Egipt } \\
\text { Ze względu na znaczenie ekonomiczne - dostarczanie ogromnej ilości zboża, } \\
\text { Egipt miał szczególne znaczenie dla Rzymu. August zorganizował prowincję Egiptu } \\
\text { na wzór osobistej domeny cesarskiej** }\end{array}$} \\
\hline Zarządzanie & $\begin{array}{l}\text { namiestnik w randze prefekta } \\
\text { imperium adsimilitudinem proconsulis, prefectus Aegypti }\end{array}$ \\
\hline $\begin{array}{l}\text { Jurysdykcja } \\
\text { sądowa }\end{array}$ & iuridicus \\
\hline $\begin{array}{l}\text { Sprawy } \\
\text { finansowe }\end{array}$ & idioslogos \\
\hline $\begin{array}{l}\text { Sprawy } \\
\text { wojskowe } \\
\text { w przypadku } \\
\text { obecności } \\
\text { garnizonu }\end{array}$ & praefecti legionum \\
\hline
\end{tabular}

Dokładna liczba prowincji o różnym statusie zarządzania zmieniała się wraz z rozwojem terytorium cesarstwa, więcej o szczegółowym podziale:W. Eck, Senatoren von Vespasian bis Hadrian. Prosopographische Untersuchungen mit Einschlußder Jahres- und Provinzialfasten der Statthalter, München 1970, s. 1-20.

${ }^{* *}$ M. Jaczynowska, op. cit., s. 260.

\subsection{Foedeus $i$ socii}

Tereny podbite zamieszkiwane były przez lokalne rody i plemiona. Z nimi to Rzymianie nawiązywali związki/przymierza - foedera, np. z Batawami czy z Ubami (ludy germańskie). Warto podkreślić, że przymierza opierały się na przyjaźni i pokoju ${ }^{32}$. Ich źródła można dopatrywać się w okresie,

32 Tak samo A. Berger, op. cit., s. 474. 
gdy Rzym utracił swoją dominującą pozycję w Lacjum, na przełomie IV i V wieku p.n.e. ${ }^{33}$ Wtedy to Rzymianom zależało na zdobyciu przychylności i wzmocnieniu własnych sił, a więc znalezieniu sprzymierzeńców. Postanowienia przymierza określały prawa i obowiązki sojuszników - socii, $\mathrm{z}$ zachowaniem pełnej samodzielności w regulowaniu swoich spraw wewnętrznych ${ }^{34}$. Tak więc ich władza wewnętrzna, kontrola finansów czy system prawny były w pełni od Rzymu niezależne. Przywileje dla sojusznika płynące $z$ zawartego przymierza były często uzależnione od siły więzi z Rzymem. Mieszkańcy terenu połączonego przez foedus mieli status według lex peregrina. Zobowiązani byli do tych powinności, które ustalono w postanowieniach, np. wspomaganie własnymi siłami bojowymi legionów rzymskich.

\subsection{Reforma administracyjna Dioklecjana}

Dioklecjan dokonał usystematyzowania podziału administracyjnego Cesarstwa Rzymskiego, co było podyktowane coraz większym terenem państwa, narastającą liczbą ludności, kryzysem gospodarczym i zagrożeniem ze strony ludów barbarzyńskich.

Państwo podzielono na 4 prefektury: Oriens, Illiricum, Italię i Afrykę oraz Galię ${ }^{35}$. Na ich czele stali prefekci pretorianów (prefecti pretorio) w randze illustris, którzy byli cywilnymi zastępcami cesarza. Prefektury dzieliły się na 12 do 15 diecezji, na których czele stali wikariusze (vicarii). Jedna diecezja mogła składać się z kilkudziesięciu do kilkuset prowincji, na czele których stali namiestnicy w randze clarissimi, zwani correctores lub praseides, proconsules czy consulares. Najmniejszą formą organizacyjną pozostały municypia.

Zamierzeniem Dioklecjana było przede wszystkim osłabienie pozycji dotychczasowych namiestników prowincji, których zdzierstwo i nadużycia mocno osłabiały finanse lokalne. Rozdzielił on także administrację wojskową od cywilnej oraz zniósł podział na prowincje ludu rzymskiego i cesarskie.

\footnotetext{
33 M. Jaczynowska, op. cit., s. 60.

${ }^{34}$ M. Kaser, op. cit., s. 58; tak samo A. Berger, op. cit., s. 709.

35 B. Sitek, Kwestie ustrojowe - rys historyczny. Dominat - późne cesarstwo rzymskie (284-565), [w:] A. Jurewicz i in., op. cit., s. 90; M. Jaczynowska, op. cit., s. 348.
} 


\subsection{Stosunki ekonomiczne i społeczne}

$Z$ jednej strony ludy podbite nadal zachowywały wpływ na sprawy wewnętrzne swojego miasta - ale już podbitego przez Rzym; z drugiej strony otrzymywały także przywileje, np. ius commerci, ius conubi, ius migrandi.

Mieszkańcy prowincji mieli względem siebie i względem Rzymu różną pozycję, co było uwarunkowane indywidualnym statusem jednostek organizacyjnych - kolonia rzymska, municypium etc. Najbardziej pożądanym przywilejem, do którego dążyli mieszkańcy było obywatelstwo rzymskie, które otwierało chociażby prawo sprawowania urzędów publicznych. Ostatecznie edykt Karakalli - Constitutio Antoniniana, około 212-214 roku n.e., rozciągnął prawo obywatelstwa rzymskiego na całą wolną ludność Cesarstwa $^{36}$. Tym samym zamknięty został proces integracji prowincji z uprzywilejowaną pod względem politycznym Italią. Korzyści z osiągania kolejnych stopni rzymskiego statusu municypium czy kolonii straciły na znaczeniu. Wyrazem tego zjawiska jest zanik gradacji civitas, municipium, colonia, a w konsekwencji pozostanie przy civitas jako miastu w ogóle ${ }^{37}$.

Nowe tereny stanowiły przede wszystkim źródło dochodów Rzymu. W zależności od statusu, czy to kolonia, czy municypium, jednostki były zobowiązane do uiszczania podatków. $Z$ czasem rujnowały one lokalne społeczności. Początkowo wszyscy obywatele rzymscy płacili podatek (tributum) określony na podstawie majątku zadeklarowanego w cenzusie. Wraz z okresem podbojów zwolniono ich z niego ${ }^{38}$. System podatkowy obowiązujący w prowincjach nie był jednolity i nie stanowił spójnego mechani$\mathrm{zmu}^{39}$. W określonej kwocie pobierano stipendium oraz w różnej wielkości podatek dzierżawny (locatio censoria). Za prawidłowości w pobieraniu podatków odpowiadali namiestnicy, którzy zlecali wykonanie zadania urzędnikom lokalnym. W okresie pryncypatu i wyróżnieniu prowincji cesarskich oraz prowincji ludu rzymskiego, dochody Cesarstwa były zasilane z dwóch

\footnotetext{
36 Zob. W. Osuchowski, Constitutio Antoniniana. Przyczyny wydania edyktu Karakalli z r. 212 w świetle współczesnych źródeł historyczno-prawnych, Roczniki Teologiczno-Kanoniczne, t. X, z. 4, s. 65 i nast.;

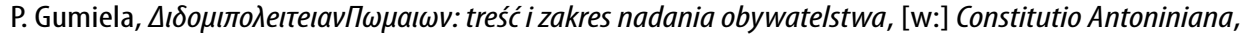
„Zeszyty Prawnicze" 2010, nr 10/1, s. 129-147.

37 T. Kotula, op. cit., s. 447.

38 M.T. Cicero, De officiis, s. 2, 76.

39 J. Zabłocki, A. Tarwacka, op. cit., s. 115.
} 
źródeł: podatki z terenów prowincji ludu rzymskiego zasilały skarb państwa - aerarium populi Romani; podatki z terenów prowincji cesarskich zasilały skarb cesarski - fiskus Caesaris. Właściciele gruntów prowincjonalnych, nawet w przypadku posiadania obywatelstwa rzymskiego, nie mogli być zwolnieni z płacenia trybutu ${ }^{40}$. Tym samym powstała niejasność, ponieważ jednocześnie w użytku były dwa terminy: stipendium i tributum jako określenie podatku prowincjonalnego ${ }^{41}$. Warto zwrócić uwagę, że granice państwa rzymskiego stanowiły jednocześnie granice celne. Dodatkowo obecne były one także $w$ obrębie cesarstwa pomiędzy prowincjami. Opłaty celne były pobierane przy przekraczaniu granic oraz przy korzystaniu z dróg, mostów czy portów - portorium.

Za Augusta widoczne są próby znalezienia nowych źródeł podatków. W III wieku n.e. pojawił się zbierany nieregularnie podatek na wojsko (annona militaris). Lokalne społeczności były zobowiązane dostarczać na rzecz wojska pożywienie, zboża i inne produkty. Za pobór tego podatku odpowiadali urzędnicy municypalni, a więc okoliczna arystokracja. Sprawowanie funkcji publicznych stawało się coraz większym ciążeniem. Dlatego w okresie dominatu coraz rzadziej spotykane są akty dobrowolnych szczodrości czy rozdawnictwa. Rozciągnięcie systemu municypalnego na obszar całego Cesarstwa służyło w pierwszym rzędzie do wzmocnienia kontroli cesarskiej i poboru podatków. Spotykane jest nawet zmuszanie przez władze centralne zamożnych mieszkańców lokalnych do przyjmowania urzędów, co było związane ze współudziałem w finansach municypium. Rzymski system podatkowy nie był planowany ani przemyślany. Nie był dostosowany przede wszystkim do rozwoju gospodarczego Cesarstwa. Często podatki nakładano w sposób nieprzemyślany, bez perspektywy przewidywania zmian społeczno-ekonomicznych, jakie wywoła ich ciężar. Zwiększanie administracji i powstanie armii zawodowej zwiększało wydatki państwa. Za Augusta powrócono do opodatkowania obywateli Italii. Pogłębiający się ucisk obywateli, w szczególności rolników i producentów innych dóbr,

40 A. Pikulska-Radomska, Uwagi o rzymskim fiskalizmie epoki wczesnego cesarstwa, [w:] A. Moszyńska (red.), Studia monograficzne ofiarowane profesorowi Ryszardowi Łaszewskiemu, Studia luridica Toruniensia, t. X, 2012, s. 39.

${ }^{41}$ Zob. F. Grelle, Stipendium vel tributum. L'imposizione fondaria nelle dottrine giuridiche del II e III secolo, Napoli 1963. 
postępująca inflacja i spadek wartości pieniądza doprowadziły do upadku gospodarczego cesarstwa ${ }^{42}$.

\section{ORGANIZACJA WEWNĘTRZNA}

W świadomości Rzymian terytorium ich organizacji państwowej stanowiły miasta i osady, dlatego to one były podstawą organizacji administrowania Cesarstwem Rzymskim ${ }^{43}$.

Większość codziennych obowiązków, składających się na zarządzanie municypium, pozostawała w rękach lokalnych urzędników, a tylko o najważniejszych rzeczach decydowano bezpośrednio z Rzymu. Dla większości mieszkańców ówczesnego państwa rzymskiego okolica, w której mieszkali stanowiła w ich świadomości cały świat - z poziomu ich origo - i w takich granicach kończyła się ich wyobraźnia o aparacie państwowym jako organizacji, której są częścią. Sprawowanie funkcji urzędniczych było, podobnie jak w Rzymie, zajęciem honorowym - ius honararium. Urzędnicy wyżsi nie pobierali wynagrodzenia za swoją działalność, wręcz byli zobowiązani do czynienia pewnych nakładów finansowych w związku z pełnioną funkcją $^{44}$. Wynagrodzenie za swoją pracę otrzymywali natomiast urzędnicy pomocniczy. Czas sprawowania urzędu wynosił najczęściej rok, zmiana osoby urzędnika następowała zatem dość często. $Z$ reguły były to także urzędy kolegialne. Tym samym proces ten często przypominał ciąg funkcji przyjaciól, ekspertów, pomocników, jak również członków wielkich domów arystokratycznych.

\footnotetext{
420 niewydolności systemu podatkowego: B. Barlett, How Excessive government killed Ancient Rome ,,"Cato Journal" jesień 1994, vol. 14, nr 2.

43 Zob. J. Edmondson, Cities and Urban Life in the Western Provinces of the Roman Empire, 30 BCE-250 CE, [w:] D. Potter (red.), A Companion of the Roman Empire, Oxford 2006, s. 250 i nast.

${ }^{44} \mathrm{~Np}$. obowiązek organizacji igrzysk przez duumwirów w mieście Urso, lex coloniae genetivae luliae s. Ursonensis LXX, tekst za FIRA I, 21, op. cit., s. 177-198 (dalej: lex Urs.).
} 


\subsection{Aparat ustrojowy}

\subsubsection{Comitia - zgromadzenia ludowe}

Zgromadzenia ludności municypalnej podejmowały uchwały i były zorganizowane na wzór rzymskich zgromadzeń okresu republikańskiego. Uchwały dotyczyły m.in. zawarcia pokoju, wypowiedzenia wojny czy wydania wyroku śmierci. Zgromadzenia pełniły również funkcję wyborcza, tj. wybierały osobę do sprawowania urzędu duumwira, edyla i kwestora, a także kolegia kapłańskie.

Obok najbardziej powszechnych comitia, można spotkać concilia, a czasami wręcz populus ${ }^{45}$. Z czasem rola zgromadzeń była marginalna. Było to odzwierciedlenie ogólnego zaniku znaczenia zgromadzeń ludowych i plebejskich w Rzymie ${ }^{46}$. Ich uprawnienia stopniowo przejmowało ordo decurionum ${ }^{47}$.

\subsubsection{Ordo decurionum}

Jako ordo należy rozumieć warstwę w społeczeństwie municypalnym, która pełniła określone funkcje ${ }^{48}$. Stanowiła ona lokalną arystokrację i była organem gremialnym, uprawnionym do reprezentowania municypium na zewnątrz, wobec innych miast oraz cesarza. Struktura ta była wzorowana na rzymskim senacie okresu republikańskiego, czyli z reguły ordo liczyło stu dekurionów (centumviri) ${ }^{49}$. W mniejszych municypiach liczba ta była mniejsza w stosunku do wielkości jednostki, ale zawsze była to liczba stała w obrębie danego municypium. Uprawnienia ordo były znacznie mniejsze niż senatu ${ }^{50}$.

Przynależność do ordo była funkcją dożywotnia, a w praktyce nawet dziedziczna, co jest wyjątkiem wobec zasady kadencyjności urzędów

\footnotetext{
45 T. Kotula, Les origines des assemblées provinciales dans l'Afrique Romaine , „Eos" 1962, z. 52, s. 147 i nast.

${ }^{46}$ K. Kolańczyk, Prawo rzymskie, Warszawa 2007, s. 40; J. Zabłocki, A. Tarwacka, op. cit., s. 169.

47 Od czasów Wespazjana zgromadzenia ludowe traciły na znaczeniu zarówno w Rzymie, jak i w prowincjach. Ich funkcję przejął w Rzymie senat, a na prowincjach ordo deurionum.

$48 \bar{O}$ rdō, inis - rząd, warstwa, tak K. Kumaniecki, op. cit., s. 346; Sondel jako szereg w znaczeniu warstwa społeczna - J. Sondel, op. cit., s. 698.

49 B. Sitek, Organy władzy w municypium Irni. Ze studiów nad prawem municypalnym w Starożytnym Rzymie ,,Journal of Modern Science" 2005, nr 1/1, s. 31.

50 B. Sitek, Decreta decurionum. Postanowienia rady miejskiej w świetle lex Irnitana, [w:] W. Uruszczak i in. (red.), Leges sapere. Studia i prace dedykowane profesorowi Januszowi Sondlowi w pięćdziesiątą rocznice pracy naukowej, Kraków 2008, s. 509; B. Sitek, Organy władzy..., op. cit., s. 31.
} 
rzymskich ${ }^{51}$. Dekurioni byli wpisani na listę - album decurionum, którą uzupełniali duumwirowie ${ }^{52}$. Lista była aktualizowana co 5 lat przez cenzora lub urzędnika zwanego quinnqenalis. Niepełny skład dekurionów mógł być uzupełniony również przez coopatio, którego dokonywali aktualnie urzędujący dekurioni z inicjatywy duumwirów ${ }^{53}$.

W skład ordo wchodzili najczęściej byli urzędnicy municypalni, w pierwszej kolejności zostawali nimi duumwirowie po ukończeniu kadencji. Aby zostać dekurionem, należało spełniać pewne kryteria ${ }^{54}$. Były to osoby wolno urodzone (ingenui), posiadające pełnię praw obywatelskich i posiadające odpowiedni cenzus majątkowy, ponieważ ponosili odpowiedzialność swoim majątkiem za zobowiązania miasta. Nie bez znaczenia było dobre imię rodu, z którego wywodzili się poszczególni dekurioni ${ }^{55}$. Dekurion musiał cieszyć się nieposzlakowaną opinią. Nie mógł nim zatem zostać aktor ani gladiator, bo były to zawody infamizujące. Dekurion musiał zamieszkiwać w mieście lub w pobliżu miasta, do którego ordo należa ${ }^{56}$. W przeciwnym razie był pozbawiany swojego statusu. Obowiązywał też odpowiedni wiek, co było różnorodnie uregulowane w różnych municypiach. Wszyscy dekurioni w różnych prowincjach byli wobec siebie równi, tzn. mieli wobec siebie tę samą pozycję prawną. Co istotne, w ogóle nie brano pod uwagę kwalifikacji zawodowych kandydata do ordo decurionum. Na koniec swojej kadencji dekurioni mieli możliwość otrzymania obywatelstwa rzymskiego.

Do głównych obowiązków dekurionów należało przede wszystkim uczestniczenie $\mathrm{w}$ obradach ordo i stanowienie lokalnego prawa. Jako lokalny senat, ordo wydawało dekrety (decreta decurionum), które miały formę jednostkowego rozstrzygnięcia administracyjnego lub charakter normy

\footnotetext{
51 J. Zabłocki, A. Tarwacka, op. cit., s. 144.

52 Zob. H. Horstkotte, Das Album von Timgad und die Bindung von Staatsbeamten an die Kurie, ZPE 75 (1988), s. 237 i nast.

53 Por. lex Irnitana XXXU, tekst za: B. Sitek, Lex coloniae..., op. cit., s. 92-209 (dalej: lex Irn.); tabula Heracleensis, s. 83-88, tekst za: C.G. Bruns, Fontes Iuris Romani Antiqui, Tybinga 1909, s. 102-110 (dalej: tab. Her.).

54 B. Sitek, 0 ciężkiej doli decuriones w okresie późnego cesarstwa rzymskiego. Uwagi poczynione na podstawie wybranych konstytucji cesarskich, [w:] Procesy ujednolicania prawa prywatnego w świetle integracji europejskiej. Rola samorzqdu terytorialnego w kształtowaniu procesu integracji europejskiej na przykładzie doświadczeń samorzq̨du w Polsce i we Włoszech, Szczecin 2002, s. 110; K. Christ, op. cit., s. 62.

55 W. Eck, Köln in römischer Zeit. Geschichte einer Stadt im Rahmen des Imperium Romanum, Köln 2004, s. 315; K. Christ, op. cit., s. 61.

56 Lex Urs. XCI.
} 
generalnej ${ }^{57}$. Treść dekretów była proponowana przez duowirów i musiała być zgodna z postanowieniami ustawy municypalnej oraz prawem obowiązującym w Rzymie. Uchwały dekurionów dotyczyły z reguły funkcjonowania lokalnej społeczności, a więc były to sprawy publiczne. Wyjątkiem były decyzje z zakresu prawa prywatnego ${ }^{58}$.

Ordo zarządzało finansami publicznymi w ten sposób, że przygotowywało budżet ${ }^{59}$, wydawało decyzje w sprawie dystrybucji pieniędzy publicznych pomiędzy mieszkańców lub kolonów należących do municypium, a także alienacji nieruchomości, a tym samym umniejszania majątku municypium czy zwolnienia z długu lub zaciągnięcia pożyczki ${ }^{60}$. Na podstawie uchwały dekurionów powierzano wykonanie zadań publicznych. Osoby, które tego dokonywały musiały w określonym czasie rozliczyć się z poniesionych wydatków w ten sposób, że sporządzały sprawozdanie z wydatkowania środków publicznych i miały obowiązek zwrócenia do kasy publicznej tego, co zostało ${ }^{61}$.

Inne sprawy, których dotyczyły dekrety ordo, to kwestie porządkowe i administracyjne, wyznaczanie miejsc na wystawienie dokumentacji publicznej, prowadzenie prac budowlanych i remontowych w obrębie murów miejskich, wykonywanie robót publicznych związanych z obronnością miasta. Do dekurionów należała także inicjatywa organizacji uroczystości religijnych czy zabaw publicznych. Funkcja kreatywna dekurionów polegała na tym, że mogli oni wskazać cesarzowi kandydata na urząd duowira oraz aprobowali kandydatów do służby urzędniczej i ustalali ich wynagrodzenie. Dekretem dekurionów można było także zezwolić na wyzwolenie niewolnika przez osobę, która nie ukończyła 20 lat ${ }^{62}$.

Ważnym uprawnieniem dekurionów była funkcja minus legationis, czyli wysyłanie poselstwa do cesarza czy innego municypium ${ }^{63}$. Istotne jest, że dekurion wybrany do poselstwa miał bezwzględny obowiązek uczestniczenia

\footnotetext{
57 B. Sitek, 0 ciężkiej doli..., op. cit., s. 110.

58 B. Sitek, Decreta decurionum, op. cit., s. 513.

59 Lex Irn. LXXIX.

60 Lex Irn. LXXX.

61 Por. Lex Urs. LXXX.

62 B. Sitek, Autonomie..., op. cit., s. 279.

63 Zob. D. Johnston, Munificence and municipia: Bequests to towns in classical roman law , Journal of Roman Studies" 1985, nr LXXV, s. 105 i nast.
} 
$\mathrm{W}$ delegacji ${ }^{64}$. W przypadku niemożności odbycia poselstwa należało $\mathrm{z}$ tego samego ordo wyznaczyć swojego zastępcę. Za niewywiązanie się z tego obowiązku nakładana była kara grzywny.

Dekurioni mieli wyjątkowo możliwość wydawania decyzji ad hoc o poszerzeniu kompetencji danego urzędnika, np. przydzielenie nowych zadań edylom ${ }^{65}$.

Z czasem przynależność do ordo decurionum stawała się dużym obciążeniem finansowym. Niejednokrotnie dekurioni pokrywali koszty związane z pełnionym urzędem $z$ własnej kieszeni. Tym samym ich ranga społeczna malała, a oni sami czuli się coraz bardziej ograniczeni w swojej swobodzie ${ }^{66}$. Jednak inskrypcje i statuty są dowodem, że dawną świetność cywilizacyjną ośrodków miejskich, jak również otoczenie kulturowe zawdzięczano właśnie dekurionom ${ }^{67}$. To dzięki ich działalności powstawały budynki użyteczności publicznej, akwedukty, miejsca kultu i to dzięki ich funduszom organizowano święta i uroczystości.

\subsection{Aparat wykonawczy}

Na czele całej prowincji stał nadany przez Rzym namiestnik - rector provinciae. Wywodził się najczęściej ze stanu senatorskiego. Gdy rozpoczynał podróż na teren prowincji, towarzyszyli mu liczni pomocnicy ze stanu senatorskiego i rycerskiego: pisarze, liktorzy. Stanowili oni przyszłe zaplecze urzędnicze dla poszczególnych miast. Liczba namiestników zwiększała się w miarę powoływania nowych prowincji, rekrutacja urzędników odbywała się regionalnie; kandydaci mianowani na urzędników administracyjnych nie musieli odznaczać się wiedzą fachową. Bardziej stawiano na ich mobilność i zaangażowanie przy wykonywaniu prac zleconych.

Urzędnicy prowincjonalni, odpowiedzialni za zarządzanie poszczególnymi municypiami, mieli być węzłem łączącym Rzym z prowincjami. Głównymi zasadami przy zajmowaniu urzędów była kolegialność i kadencyjność.

\footnotetext{
${ }^{64}$ Lex Urs. LXXXXII, lex Irn. XLV.

65 Taki wyjątek spotykany jedynie w lex Irnitana XIX, mowa tu o przeprowadzeniu egzekucji z pignorescapionem wobec municipes i incolae do wysokości 10000 sestercji na osobę jednego dnia oraz możliwości nakładania kary na te osoby nie wyższych niż 5000 sestercji na osobę jednego dnia.

66 Zob. A. Baumann, Freiheitsbeschränkungen der Dekurionen in der Spätantike, Hildesheim-Zürich-New York 2014.

67 K. Christ, op. cit., s. 63; H.S. Sivan, Town, country and province in late roman gaul: the example of CIL XIII 128, „Zeitschrift für Papirologie und Epigraphik"1989, z. 79, s. 108.
} 
W praktyce niemalże każda funkcja była sprawowana przez dwóch urzędników przez okres jednego roku - na wzór republikański.

Urzędnicy prowincjonalni byli wybierani z reguły na rok przez zgromadzenia ludowe, a z czasem przez ordo, które przejęło funkcje zgromadzeń. Osoby wybrane na wyznaczone posady miały obowiązek złożenia przysięgi przed objęciem funkcji (iusiurandum in legem) ${ }^{68}$. Obowiązywało to zarówno duumwirów, edylów i kwestorów, jak i urzędników pomocniczych, np. pisarzy. Było to przekalkowanie zwyczaju republikańskiego, kiedy to urzędnicy składali dwukrotnie przysięgę - raz po wyborze na urząd, a przed ogłoszeniem wyboru, a drugą w ciągu 5 dni od objęcia urzędu. W municypium przysięgę składano tylko raz, wobec największych bóstw: Jowisza, bóstw domowych, jak również deifikowanych cesarzy. Odbywało się to najczęściej na początku obrad zgromadzeń ludowych, a treść obejmowała zobowiązanie do należytego wykonywania swojej funkcji, zgodnie z ustawą municypalną. Niezłożenie przysięgi było usankcjonowane grzywną.

\subsubsection{Duoviri iure dicundo}

Na czele municypium stali duumwirowie (duumviri), którym były przypisane wybrane kompetencje niższej jurysdykcji ${ }^{69}$. W kolonii czy prowincji było ich dwóch, w przypadku municypium mówi się nawet o czterech mężach, a więc quattuorviri iure dicundo ${ }^{70}$. W Afryce można spotkać przypadki nawet triumviri, quinqeviri, octoviri, decemviri, undecemprimi. Jednak nie wiadomo, jakie tak naprawdę pełnili funkcje i dlaczego organy te były tak liczne. Możliwe, że były to zachowane pierwotne formy sprawowania władzy, jeszcze z czasów przedrzymskich ${ }^{71}$.

Funkcja duumwira łączyła się ze swoistym prestiżem. Symbolami pozycji duumwira były toga bramowana purpura, rózga, a także liktorzy i kilku urzędników pomocniczych (apparitores). Nie należy zapominać o takich kwestiach, jak przyporządkowanie najlepszych miejsc podczas igrzysk czy $\mathrm{w}$ teatrze $\mathrm{e}^{72}$. Jest to odbicie zasad panujących w Rzymie, gdzie senatorowie

68 Lex Irn. XXVI; lex Urs. LXXXI; lex tabulae Bantinae 1. 19, FIRA I, 19, op. cit., s. 164; lex municipii Malacitani, 59, FIRA I, 24, op. cit., s. 210.

${ }^{69} \mathrm{G} \mathrm{I} 23 ; \mathrm{N} 162 ;$ CIL 13, 7918.

70 T. Bechert, Germania inferior..., op. cit., s. 38; por. Lex municipii Tarentini IX 1, FIRA I, 18, op. cit., s. 167.

71 L.A. Curchin, The local magistrates of Roman Spain, Toronto 1990, s. 7-9.

72 Lex Urs. CXXV, tab. Her. II. 126-134. 
i ekwici mieli odpowiednie przywileje, również miejsca w amfiteatrach sobie przypisane.

Duumwirowie zwoływali obrady ordo oraz przewodniczyli im. Do nich należała wyłączność inicjatywy ustawodawczej dla dekretów dekurionów. Poprzez złożenie wniosku o wydanie dekretu - postulatio - wszczynano procedurę uchwałodawczą ${ }^{73}$. Duumwir przedstawiał sprawę do uregulowania przez publiczne odczytanie przed ordo decurionum - recitatio.

Duumwirowie dysponowali środkami publicznymi. Ciekawym obowiązkiem było m.in. zorganizowanie igrzysk dla ludności. Był to zwyczaj rzymski przeniesiony do prowincji. W kolonii Urso wszyscy duumwirowie $\mathrm{w}$ trakcie swojego urzędowania byli zobowiązani na podstawie uchwały dekurionów do organizacji igrzysk lub przedstawień teatralnych na cześć Jowisza, Junony, Minerwy i innych bogów i bogin ${ }^{74}$. Na organizację wydarzeń musieli oni wydać swoje pieniądze w kwocie nie mniejszej niż 2000 sestercji, a z pieniędzy publicznych mogli wydać kwotę nieprzekraczającą 2000 sestercji. Taki sam obowiązek mieli w tym mieście edylowie ${ }^{75}$.

Po ukończeniu kadencji duumwirowie otrzymywali obywatelstwo rzymskie i wchodzili w skład ordo decurionum. Można zastanawiać się, czy członkostwo w ordo decurionum było niezbędnym warunkiem otrzymania obywatelstwa rzymskiego ${ }^{76}$.

\subsubsection{Duoviri aedilicia potestate (edylowie)}

Niższymi stopniem byli duowirowie edylni - duoviriaediles, urząd kolegialny wzorowany na rzymskich edylach kurulnych. Sprawowali przede wszystkim funkcję policyjną77. Ich głównym zadaniem było zapewnienie porządku i bezpieczeństwa w mieście, szczególnie w miejscach publicznych: obiektach kultu i sakralnych, murch, na drogach i targowiskach ${ }^{78}$. Odpowiadali również za aprowizację municypium w odpowiednie ilości żywności.

\footnotetext{
73 B. Sitek, Organy władzy..., op. cit., s. 33.

74 Lex Urs. LXX.

75 Lex Urs. LXXI.

76 Zob. H. Horstkotte, Dekurionat und römisches Bürgerrecht nach der lex Irnitana, „Zeitschrift für Papyrologie und Epigraphik" 1989, z. 78, s. 169 i nast.

77 G 5 i 292; CIL 13, 7981.

78 Lex Irn. XIX.
} 
W hierarchii edylowie podlegali duumwirom. Ich kompetencje mogły być każdorazowo rozszerzane przez dekurionów lub duowirów.

\subsubsection{Kwestorzy}

Kwestorzy odpowiadali za finanse publiczne miasta: pobieranie podatków, dysponowanie pieniędzmi publicznymi, troszczyli się o stan finansów publicznych. Zakres ich kompetencji szczegółowo określały ustawy municypalne, np. współdziałania przy realizacji dzierżawy, obowiązku utrzymania drogi ${ }^{79}$. Kwestorzy wydawali dekrety.

\subsubsection{Urzędnicy pomocniczy - apparitores}

Osoby sprawujące urzędy wyższe nie byłyby w stanie dobrze wykonywać swoich zadań, gdyby nie grono osób im w tym pomagających. Urzędnicy pomocniczy - apparitores, mieli za zadanie właśnie wspomagać funkcjonowanie urzędu duumwira lub edyla w wykonywaniu swoich zadań. Było ich kilku i były to osoby wyspecjalizowane w swoich czynnościach. Zaliczyć tu można pracowników sądowych (lictores), woźnych (accensos), pisarzy (scribas), gońców (viatores), przepisywaczy (librarium), heroldów (praecones), wróżbitę (haruspex) i fletnistę (tibicen). Przykładowo, osoba pełniąca funkcję duumwira w kolonii Urso była uprawniona do posiadania 2 liktorów, 1 woźnego, 2 pisarzy, 2 gońców, przepisywacza, herolda, wróżbity i fletnisty ${ }^{80}$.

Urzędnicy pomocniczy byli opłacani oraz uprzywilejowani w ten sposób, że nie pełnili służby wojskowej w roku sprawowania przez nich urzędu. Wyjątkiem było zagrożenie bezpieczeństwa publicznego. W kolonii Urso przykładowe wynagrodzenie pisarza służącego duumwirowi wynosiło 1200 sestercji, wróżbity $-500^{81}$. Natomiast pisarz służący edylowi otrzymywał 800, a wróżbita 100 sestercji $^{82}$. Tak więc wysokość wynagrodzenia zależała od pozycji urzędu, któremu pomagano. Okres sprawowania funkcji urzędników trwał do 31 grudnia, do rozpoczęcia kalend styczniowych, a wynagrodzenie przysługiwało dopiero po przepracowaniu $1 / 4$ roku $^{83}$.

\footnotetext{
79 Tab. Her. $46-49$.

80 Lex Urs. LXII.

81 Lex Urs. LXII.

82 Lex Urs. LXII.

83 Lex Urs. LXIII.
} 


\subsubsection{Urzędnicy nadzwyczajni}

Urzędnicy nadzwyczajni byli powoływani w określonych okolicznościach do określonych funkcji. Byli to prefekci, pełnomocnicy municypium lub kuratorzy.

W inskrypcjach można spotkać prefectus imperatoris (caesaris) oraz prefectus iure dicundo ${ }^{84}$. Pierwszy reprezentował cesarza w municypium i bronił jego interesów. Samodzielnie zarządzał miastem, co było wyjątkiem od zasady kolegialności ${ }^{85}$. Okres sprawowania urzędu wynosił 5 lat, a kandydat nie musiał spełniać wymogów stawianych kandydatom do innych urzędów lokalnych. Najczęściej funkcję tę sprawowali członkowie rodziny cesarskiej lub osoby z najbliższego otoczenia władcy. Prefectus iure dicundo zastępował duumwirów podczas ich nieobecności.

Pełnomocnika municypium (actor) mianowały uprawnione podmiot, np. ordo decurionum ${ }^{86}$, a jego zadaniem była reprezentacja municypium w procesach i przeprowadzaniu czynności prawnych, gdzie stroną było municypium. Kandydat na pełnomocnika musiał odznaczać się pewnymi kwalifikacjami ${ }^{87}$.

Kuratorzy byli odpowiedzialni za kontrolę finansów miast italskich, a następnie prowincjonalnych. W obliczu kryzysu na przełomie II i III wieku n.e. spadła wartość pieniądza, osłabiło się rzemiosło i handel. Za Trajana we wschodnich częściach Cesarstwa trudnościami finansowymi zajmowali się curatores civitatis, którzy byli powoływani spoza grupy urzędników municypalnych. Mieli oni za zadanie uporządkować finanse miasta i zrównoważyć budżet. Szybko stali się oni narzędziem kontroli cesarskiej, a za panowania Sewerów ich powoływanie stało się regułą. Usilne poszukiwanie finansowania Imperium prowadziło do niemałego ograniczenia autonomii municypiów.

\subsection{Sądownictwo}

Uprawnienia jurysdykcyjne były przypisane określonym urzędom publicznym i wiązały się bezpośrednio z ich funkcją. Sądownictwo rzymskie był

\footnotetext{
84 B. Sitek, Autonomie..., op. cit., s. 287.

85 Lex Irn. XXIV.

${ }^{86}$ Lex Irn. LXX.

87 B. Sitek, Autonomie..., op. cit., s. 288.
} 
reprezentowane przez urzędników rzymskich w miastach prowincjonalnych, a uprawnienia jurysdykcyjne poszczególnych urzędników regulowała ustawa municypalna. Tym samym wobec braku zachowanych źródeł trudno jest odtworzyć system sądownictwa we wszystkich municypiach i stworzyć wspólny jego schemat obowiązujący prowincje.

Cezurę we właściwości rzeczowej urzędnika, co do orzekania w sporze, określała wartość przedmiotu sporu ${ }^{88}$. Mimo takiego podziału, nie można mówić tu o dwuinstancyjności, a o właściwości rzeczowej danego urzędnika co do rozwiązania sporu.

Władza sądownicza spoczywała w rękach pretora w okresie republikańskim, którego funkcje jurysdykcyjne przejęli namiestnicy od okresu Sulli ${ }^{89}$. Sprawy mieszkańców prowincji były rozpatrywane przez trybunał, tworzony przez namiestnika i radę - consiliom - Rzymian zamieszkujących na danym obszarze. Co istotne, od wyroku namiestnika nie było odwołania.

Sprawując jurysdykcję w drobnych sprawach cywilnych oraz lżejszych sprawach karnych, duumwirowie byli podstawowym organem wymiaru sprawiedliwości w municypium. Te uprawnienia były ich uprawnieniami zwyczajnymi i nie mogli ich delegować na innych urzędników, co mogłoby zostać odczytane jako wykorzystanie władztwa administracyjnego lub militarnego ${ }^{90}$. Wyznacznikiem właściwości jurysdykcyjnej duumwirów była wartość przedmiotu sporu różna dla różnych municypiów. Przykładowo w municypium Irni było to 1000 sestercji ${ }^{91}$, w Gali Przedalpejskiej- $15000^{92}$ lub $10000^{93}$ sestercji. Powyżej tej kwoty spory rozstrzygał namiestnik prowincji.

Wyjątkiem wspomnianym tylko w lex Irnitana jest okoliczność, że także edylowie mieli uprawnienia jurysdykcyjne. Mieli oni możliwość powoływania sędziów i recuperatores w przypadku wartości sporu niższej niż 1000 sestercji, a więc mieli oni takie samo uprawnienie jak duowirowie w tym mieście $^{94}$. Dekurioni mieli niewielkie uprawnienia sądowe, m.in. możliwość

\footnotetext{
88 Zob. A. Rodger, Jurisdictional limits in the lex Irnitana and the lex de Gallia Cisalpina, "Zeitschrift für Papyrologie Epigraphik" 1996, nr 110, s. 189-206.

${ }^{89}$ M. Kaser, op. cit., s. 57.

90 Por. lex Urs. LXXXIV czy lex Irn. LXXXIV.

91 Lex Irn. LXXXIV.

92 Lex de Gallia cisalpina vulgo lex rubria. XXII, FIRA I, 19, op. cit., s. 174.

93 Fragmentum Atestinum 7, FIRA I, 20, op. cit., s. 177.

94 Lex Irn. XIX.
} 
wszczęcia procesu w przypadku wniesienia skargi przez obywatela w imieniu municypium, gdy strona przeciwna nie chciała wdać się $\mathrm{w}$ proces ${ }^{95}$, o ile wartość przedmiotu sporu nie przekraczała 500 sestercji. Gdy była to wartość wyższa, właściwy był namiestnik prowincji. Ordo stanowiło także instytucję odwoławczą w stosunku do postanowień duumwirów nakładających grzywny. Dekurioni odbierali przysięgi składane przez sędziów.

Sądy municypalne stosowały proces formułkowy, składający się z części in iure i apud iudicem. Proces legisakcyjny był dlatego niewłaściwy, że był dopuszczalny tylko pomiędzy obywatelami rzymskimi ${ }^{96}$. Pierwszą część procesu formułkowego in iure, czyli rozpoznanie sprawy, dokonywał duumwir. Następnie przekazywał sprawę do rozstrzygnięcia sędziemu, arbitrowi lub recuperatores. Ci ostatni funkcjonowali na zasadach obowiązujących w Rzymie ${ }^{97}$. Sędziowie jednostkowi byli wpisani na listę-albumiudicum, corocznie weryfikowanej przez duumwirów i zatwierdzanej przez namiestnika prowincji ${ }^{98}$. Sędziami mogli zostać albo dekurioni albo zwykli obywatele municypium. Proces formułkowy był o tyle dogodny dla sądownictwa municypalnego, że jego mniejsza formalność dawała szerszą ochronę praw prywatnych w różnych sytuacjach życiowych, nawet wtedy, kiedy ius civile nie dawało ochrony ${ }^{99}$. W procesie formułkowym zdolność procesową mieli, obok Rzymian i Latynów, także peregryni ${ }^{100}$.

Zakres jurysdykcji sądów lokalnych zależał od zakresu autonomii miasta: większa autonomia - większa jurysdykcja, ograniczona autonomia - ograniczona jurysdykcja ${ }^{101}$.

95 B. Sitek, Autonomie..., op. cit., s. 318.

96 W. Wołodkiewicz, M. Zabłocka, Prawo rzymskie. Instytucje, Warszawa 1996, s. 286.

97 D. Johnston, Three thoughts on roman private law and the lex Irnitana ,,Journal of Roman Studies" 1987, nr LXXVII, s. 67.

98 B. Sitek, Autonomie..., op. cit., s. 315.

99 K. Kolańczyk, op. cit., s. 128.

100 W. Wołodkiewicz, M. Zabłocka, op. cit., s. 283.

101 W. Bojarski, op. cit., s. 20. 


\section{PODSUMOWANIE}

Analizując charakter administracji municypalnej w starożytnym Rzymie oraz zastanawiając się nad dzisiejszym system samorządu terytorialnego, można by dopatrzeć się kilku cech wspólnych. Społeczność lokalna municypium decydowała o swoich sprawach, podobnie jak dzisiejsze gminy. Głos zgromadzenia ludowego przypomina po części instytucję referendum gminnego. Funkcje i zadania były podzielone systematycznie, np. obowiązki porządkowe edylów są po części zbieżne z funkcją policji i straży miejskiej, a sprawy finansowe w rękach kwestora przypominają o instytucji skarbnika gminy. W ordo decurionum można upatrywać funkcji dzisiejszej rady miejskiej, wraz z przewodniczącymi im dekurionami w funkcji zarządu gminy. Podobieństwa można doszukiwać się również w zgodności decyzji organów municypium z ustawą municypalna, kadencyjności urzędów czy ich kolegialności. W dalszej kolejności jest jawność funkcjonowania urzędów, ponieważ decyzje musiały być podawane do wiadomości publicznej ${ }^{102}$, odpowiednie kwalifikacje na urzędnika, ich odpowiedzialność, obowiązek złożenia przysięgi przed objęciem urzędu.

Imperium Rzymskie stworzyło system na potrzeby swojej polityki ekspansji, przede wszystkim podbojów nowych ziem i stworzenia potęgi światowej. Cel ten należy uznać za osiaggnięty. Ze względu na odmienność świadomości ówczesnych mieszkańców Rzymu czy różnic kulturowych powyższe porównywanie jest zbyt daleko idące. O wiele bardziej realne byłoby dopatrywanie się w rzymskiej polityce ekspansji podwalin unijnej polityki regionalnej. W świadomości Rzymianina nie istniały państwa jako wyodrębnione jednostki administracyjne. Istniały natomiast ludy i zamieszkane przez nie tereny. Dzisiejsza Unia Europejska, mimo państw członkowskich, widzi Europę również poprzez regiony czy subregiony. Taka analiza pokazuje, jak doniosłe były osiągnięcia Rzymian dla kształtu prawno-politycznego dzisiejszej Europy.

${ }^{102}$ Funkcja tabulae publicae w tab. Her. II 13-16. 


\section{BIBLIOGR AF I A}

Barlett B., How Excessive government killed Ancient Rome, „Cato Journal” jesień 1994, vol. 14, nr 2.

Baumann A., Freiheitsbeschränkungen der Dekurionen in der Spätantike, Hildesheim-Zürich-New York 2014.

Bechert T., Die Provinzen des Römischen Reiches. Einführungund Überblick, Mainz 1999.

Bechert T., Germania inferior. Eine Provinz an der Nordgrenze des Römischen Reiches, Mainz 2007.

Berger A., Encyclopedic Dictionary of Roman Law, Philadelphia 1953 (reprint z 1980).

Bojarski W., Stosunki cesarskiego Rzymu z lokalnymi autonomiami w zakresie sadownictwa, [w:] Dzieje wymiaru sprawiedliwości, Koszalin 1999.

Bruns C.G., Fontes Iuris Romani Antiqui, Tybinga 1909.

Christ K., Die Römische Kaiserzeit, München 2001.

Cicero M.T., De officiis, red. H. Gunermann, Stuttgart 1976.

Cicero M.T., Orationes, In Verrem Ii 2-7.

Curchin L.A., The local magistrates of Roman Spain, Toronto 1990.

Eck W., Agrippina - die Stadtgründerin Kölns. Eine Frau in der frühkaiserzeitlichen Politik, Köln 1993.

Eck W., Die Leitung und Verwaltung einer prokuratorischen Provinz, [w:] Die Verwaltung des Römischen Reiches in der hohen Kaiserzeit. Ausgewählte under weiterte Beiträge, t. 1, Basel-Berlin 1995.

Eck W., Die Struktur der Städte in den nordwestlichen Provinzen und ihr Beitrag zur Administration des Reiches, [w:] W. Eck, H. Gailsterer (red.), Die Stadt in Oberitalien und den nordwestlichen Provinzen des römischen Reiches, Kölner Forschungen 4, Mainz 1991.

Eck W., Die Verwaltung des Römischen Reiches in der Hohen Kaiserzeit: ausgewählte und erweiterte Beiträge, t. 2, Basel-Berlin 1997.

Eck W., Köln in römischer Zeit. Geschichte einer Stadt im Rahmen des Imperium Romanum, Köln 2004.

Eck W., Senatoren von Vespasian bis Hadrian. Prosopographische Untersuchungen mit Einschlußder Jahres- und Provinzialfasten der Statthalter, München 1970.

Edmondson J., Cities and Urban Life in the Western Provinces of the Roman Empire, 30 BCE-250 CE, [w:] D. Potter (red.), A Companion of the Roman Empire, Oxford 2006.

Grelle F., Stipendium vel tributum. L'imposizione fondaria nelle dottrine giuridiche del II e III secolo, Napoli 1963. 
Gumiela P., $\Delta \iota \delta о \mu \iota \pi о \lambda e \iota \tau e \iota \alpha v \Pi \omega \mu \alpha \iota \omega v$ : treść i zakres nadania obywatelstwa, [w:] Constitutio Antoniniana, „Zeszyty Prawnicze” 2010, nr 10/1.

Horstkotte H., Das Album von Timgad und die Bindung von Staatsbeamten an die Kurie, ZPE 1988, nr 75.

Horstkotte H., Dekurionat und römisches Bürgerrecht nach der lex Irnitana, "Zeitschrift für Papyrologie und Epigraphik" 1989, z. 78.

Humbert M., Municipium et civitas sine suffragio. L'organisation de la conquétejusqu'a la guerresociale, Rzym 1978.

Hurst H., The fortress coloniae of Roman Britain: Colchester, Lincoln and Gloucester, [w:] J.H. Humphrey, S.B. Holman (red.), , Journal of Roman Archaeology", nr 38. Jaczynowska M., Historia starożytnego Rzymu, Warszawa 1979.

Johnston D., Munificence and municipia: Bequests to towns in classical roman law, „Journal of Roman Studies" 1985, nr LXXV.

Johnston D., Three thoughts on roman private law and the lex Irnitana, "Journal of Roman Studies" 1987, nr LXXVII.

Kaser M., Römische Rechtsgeschichte, Göttingen 1967.

Kolańczyk K., Prawo rzymskie, Warszawa 2007.

Kotula T., Les origines des assemblées provinciales dans l'Afrique Romaine, „Eos” 1962.

Kumaniecki K., Stownik łacińsko-polski, Warszawa 1975.

Osuchowski W., Constitutio Antoniniana. Przyczyny wydania edyktu Karakalli z r. 212 $w$ świetle wspótczesnych źródet historyczno-prawnych, Roczniki Teologiczno-Kanoniczne, t. X, z. 4.

Pikulska-Radomska A., Uwagi o rzymskim fiskalizmie epoki wczesnego cesarstwa, [w:] A. Moszyńska (red.), Studia monograficzne ofiarowane profesorowi Ryszardowi Łaszewskiemu, Studia Iuridica Toruniensia, t. X, 2012.

Rodger A., Jurisdictional limits in the lex Irnitana and the lex de Gallia Cisalpina, „Zeitschrift für Papyrologie Epigraphik" 1996, nr 110.

Sajkowski R., Kwestie ustrojowe - rys historyczny, [w:] A. Jurewicz i in., Rzymskie Prawo publiczne. Wybrane zagadnienia, Olsztyn 2011.

Sitek B., Decreta decurionum. Postanowienia rady miejskiej w świetle lex Irnitana, [w:] W. Uruszczak i in. (red.), Leges sapere. Studia i prace dedykowane profesorowi Januszowi Sondlowi w pięćdziesiąta rocznicę pracy naukowej, Kraków 2008.

Sitek B., Kwestie ustrojowe - rys historyczny. Dominat - późne cesarstwo rzymskie (284-565), [w:] A. Jurewicz i in., Rzymskie Prawo publiczne. Wybrane zagadnienia, Olsztyn 2011.

Sitek B., Lex coloniae Genetivae Iuliae seu Ursonensis i Lex Irnitiana. Ustawy municypalne antycznego Rzymu. Tekst, tłumaczenie i komentarz, Poznań 2008. 
Sitek B., O ciężkiej doli decuriones w okresie późnego cesarstwa rzymskiego. Uwagi poczynione na podstawie wybranych konstytucji cesarskich, [w:] Procesy ujednolicania prawa prywatnego w świetle integracji europejskiej. Rola samorzadu terytorialnego $w$ kształtowaniu procesu integracji europejskiej na przykładzie doświadczeń samorządu w Polsce i we Włoszech, Szczecin 2002.

Sivan H.S., Town, country and province in late roman gaul: the example of CIL XIII 128, „Zeitschrift für Papirologie und Epigraphik" 1989, z. 79.

Sondel J., Stownik łacińsko-polski dla prawników i historyków, Kraków 1997.

Wołodkiewicz W., Zabłocka M., Prawo rzymskie. Instytucje, Warszawa 1996.

Zabłocki J., Tarwacka A., Publiczne prawo rzymskie, Warszawa 2011. 